\title{
War Crimes and Expressive Theories of Punishment: Communication or Denunciation?
}

\author{
Bill Wringe
}

Published online: 31 March 2010

(C) Springer Science+Business Media B.V. 2010

\begin{abstract}
In a paper published in 2006, I argued that the best way of defending something like our current practices of punishing war criminals would be to base the justification of this practice on an expressive theory of punishment. I considered two forms that such a justification could take-a 'denunciatory' account, on which the purpose of punishment is supposed to communicate a commitment to certain kinds of standard to individuals other than the criminal and a 'communicative' account, on which the purpose of the punishment is to communicate with the perpetrator, and argued for a denunciatory account which I developed at some length. In this paper I would like to reconsider the plausibility of a communicative account. One difficulty that such accounts face is that the punishment of war criminals often involves the inflicting of harsh treatment on them by individuals who are members of states other than their own. On a communicative account this is problematic: on such an account_or at least on the version of it proposed by Duff (2000) — it is essential that those who are punish and those who punish them belong to a single community. When this requirement is not satisfied harsh treatment does not constitute punishment. Duff has argued that the problem can be solved by regarding all human beings as members of a single moral community: here I argue that this suggestion is unsatisfactory and propose an alternative. One consequence of my account is that if it is correct there may limitations on the range of kinds of war criminal that can legitimately be punished by international tribunals.
\end{abstract}

Keywords War crimes - Punishment - Expressive theory of punishment . Communication

\footnotetext{
B. Wringe $(\bowtie)$

Bilkent University, 06800 Bilkent, Ankara, Turkey

e-mail: wringe@bilkent.edu.tr
} 


\section{Introduction}

Should war criminals be punished? Or, to be more precise, should war criminals be subject to legal or quasi-legal criminals proceedings aimed at deciding questions of guilt, and, if found guilty, should they be subjected to judicially imposed penalties? If so, why?

Many people have a straightforward answer to the first and second of these questions: they think that it is at least permissible, and may in some cases be obligatory to try individuals suspected of war crimes and to impose punishments on those found guilty in such trials. Since 1945, the international community has taken steps to see this belief put into practice. And, while the practice of that community has not always matched the clarity of the convictions of some of its members, it can be seen as prima facie evidence against an entirely cynical reading of international affairs. Existing practice has its troubling aspects (Wringe 2006). In this paper, I shall take it for granted that some version of it can be justified, and I shall be concerned with one kind of account of how it might be justified. My aim is in fact to consider the relative merits of two accounts of the same general kind, both of which might be labelled 'expressive' justifications.

The two accounts I shall consider I have elsewhere (Wringe 2006) characterised as 'communicative' and 'denunciatory' accounts. In 2006, I argued for a denunciatory account and gave a somewhat cursory view of communicative accounts. Here, I aim to go beyond and partly emend what I said there, and to argue that for some kinds of case a communicative account is viable. However, I am not fully reversing myself, for I shall argue here that if we take a communicative account to provide a full normative justification of the practice of punishing war crimes, then we may be led to conclude that our current practice should be amended in some respects.

\section{Expressive, Communicative and Denunciatory Theories of Punishment}

The central idea of any expressive theory of punishment is that we should account for the justification of punitive practices in terms of the messages they communicate. This idea originates with Feinberg (Feinberg 1970), who argues that in order to understand the conceptual distinction between punishment, on the one hand, and a tax on undesirable behavior on the other, we need to bear in mind the expressive role of punishment. Feinberg sees this expressive function as puzzling, and potentially morally troubling. Nevertheless, if we accept that for something to be properly called punishment it must have an expressive dimension, we raise the possibility that this dimension plays a significant role in the justification of punishment.

There are a number of different ways in which it might do this. For example, utilitarian accounts of punishment typically try to show that judicial and punitive practices are justified by considering the net benefits of the practice, standardly taken to be given by summing up the benefits-in terms of the prevention of further crimes by the individual during periods of incarceration (or in the case of capital 
punishment, as a result of their death) and the deterrence of future criminal acts, and the costs - in terms of pain inflicted on the individual, the monetary costs of inflicting the punishment and of maintaining institutions of punishment and so on.

Deterrence involves the idea of a threat, which is of course a kind of communication. However, a utilitarian account might aim to take into account other communicative effects of punishment which go beyond simple deterrence. Punishment may not simply frighten individuals who might themselves commit crimes but also play a role in communicating the standards of a community to its members, thereby influencing their moral and social development; and it is even possible - though perhaps utopian-to imagine forms of punishment which play a role in changing the behavior of criminals not by increasing the costs of crime, but by enabling the criminal to recognize and accept new standards of behavior. ${ }^{1}$

Nevertheless, although utilitarians may be able to accommodate insights about the expressive function of punishment, many of those who have advocated expressive accounts of punishment have done so as explicit opponents of utilitarianism. For example, Anthony Duff (Duff 2001) has argued that because utilitarian accounts treat the infliction of punishment on an offender simply as a means to the end of influencing the behaviour of others, they flout the Kantian requirement to treat others as ends-in-themselves, while his account, which focusses on the idea that punishment can be a means of communicating with an offender, in which they are given the opportunity to understand and accept new standards of behaviour does not and is to be preferred for that reason.

Duff's non-utilitarian expressive account of punishment forces us to accord great significance to a distinction which utilitarian expressivists might be inclined to down-play. This is the distinction between communication which is addressed to the punished offender by means of the punishment, and communication which is addressed to other individuals - for example, to other members of the community to which the punished individual belongs, or to individuals outside that community. Only accounts which focus on the former seem able to escape the charge of treating the punished individual as a means to an end. Following Narayan (1993) I shall reserve the label 'communicative' for such accounts. Other accounts, in which the justification of punishment depends on the way in which those practices communicate with individuals other than the individual being punished, I shall call 'denunciatory'. 2

\section{Punishing War Crimes: Denunciation or Communication?}

In Wringe (2006) I argued for a denunciatory account of the punishment of war crimes, writing that the intended audience of the message which a form of punishment is intended to communicate is "not just, or even primarily the

\footnotetext{
${ }^{1}$ For examples of such accounts see especially Duff (2001), and for critical discussion Davis (1991) and the contributions to Matravers (1999).

2 'Denunciatory' may not be an entirely happy label here, since it suggests that the point of the punishment is to denounce individuals, whereas on my (2006) view the point is rather to communicate that certain standards are to be taken seriously.
} 
wrongdoer, but the society itself or even the world at large' (Wringe 2006, p. 178). I thereby explicitly differentiated my own view about war crimes from one based on Duff's more general communicative justification of punishment. I also argued that a 'denunciatory' account of punishment was likely to be superior to a communicative account in this case, pointing out that on Duff's account it is essential that the individual punished should be a member of the same community as the person or person's doing the punishing, and suggesting that it is difficult to make a case that this will be the situation in standard cases of punishment of war crimes (Wringe 2006, pp. 179-180; Duff 2009, 2010).

Two further features of my 2006 account might also make it seem superior to a communicative account patterned on Duff's. First, it provides us with a way of seeing how the expressive function of our practices of punishing war crimes complements an expressive function played by war crimes trials. I argued that the practice of subjecting war criminals and war crimes suspects to legal or quasi-legal processes

expresses a commitment to a certain ideal of justice... that... might include at least the following ideas. The first is that the use of power by those that have it not be entirely unconstrained. The second is that that power should not be exercised in a way that gives no voice to those over whom it is exercised (Wringe 2006, p. 181)

I understood the phrase 'expresses a commitment' to mean something like 'make a public declaration of a commitment', rather than simply 'act in a way such as one would act if one were so committed.' (Wringe 2006, p. 181 n. 37)

Secondly, my account entails that there is something non-standard about justifications of the punishment of war criminals. For the account presupposes that in standard cases legal processes can be given some other form of justification. If this were not so, then it would be difficult to see how trying war criminals could be seen as giving expression to a commitment to certain ideals of justice: the idea that they give expression to such ideals relies on standard cases of legal trial and punishment being a paradigm case of such ideals in action. ${ }^{3}$

\section{What Denunciatory Accounts Cannot Do}

Despite this, a communicative account of the punishment of war crimes might seem preferable to a denunciatory one for two reasons. First, a denunciatory account seems vulnerable to the objection that on it, war criminals are treated as a means to an end in much the same way as they are on a utilitarian account. On the denunciatory account, our punitive and judicial or quasi-judicial practices with respect to war criminals are justified by reference to the ways in which they allow us to express our condemnation of the acts of war criminals and our commitment to

\footnotetext{
3 At first blush it might seem odd to regard the fact that on this account the justification of our practices with respect to war crimes is non-standard as a strength of the view. However, I think it is a strength, insofar as it answers to an intuition that many have to the effect that the the punishment of war crimes is indeed anomalous.
} 
ideals of justice. But the means by which we express our commitments here is through the infliction of harsh treatment on individuals who have been deprived of their liberty. It is our treatment of other human beings which allows us to express the message that we wish to express. ${ }^{4}$ This looks very much like treating others as a means to an end.

In my 2006 paper I argued that we should treat the requirement to treat others not merely as a means but as ends-in-themselves as precluding only courses of action to which those affected by them could not in principle accept, and suggested that there is no way of showing that a war criminal could not in principle accept that their harsh treatment should serve as a message to others even though it might seem very unlikely in practice that they would accept it (Wringe 2006, p. 190).

However, whatever the merits of this reading of a requirement to treat others not merely as a means as an interpretation of Kant, it seems only to place very minimal constraints on our treatment of others. While it may rule out-for example-lying and coercion in the judicial process (so that it may not be entirely toothless in the context of my denunciatory view taken as a whole) it seems to allow for such actions as deliberately humiliating others on the grounds of their religious beliefs for the amusement of their jailers, or singling out particular individuals for harsh treatment during their imprisonment in order to affect the morale of other individuals on trial. For, however, objectionable these practices might seem, it appears to be hard to rule out the purely logical possibility that an individual who had been subjected to them might regard them as acceptable general principles. (Consider in respect of the first St. Paul's exhortation to early Christians to be prepared to be mocked for their faith.)

If this is correct, the requirement not to treat others as means needs to be beefed up. ${ }^{5}$ Arguably, what is at stake here is a distinction between a relatively easily satisfied and clear-cut requirement to treat people in ways which instantiations of abstractly specifiable Kantian rationality might in principle accept, and a requirement to treat particular concrete individuals, with their own different psychological traits in ways which they could, but may not, and possibly will not accept. As a way of getting some kind of a grip on this distinction consider the difference between a requirement which allows the religiously-based humilation of prisoners merely on the grounds that some logically possible agent might have religious beliefs which would not preclude them from accepting treatment of this sort, and a rather more demanding requirement which would rule out this kind of treatment for individuals who were members of another religious tradition-or perhaps none at all-for whom Paul's advice had no canonical standing.

A second problem with the way in which I understood the requirement not to treat people as mere means is that it fails to see a distinction which one might take to be implicit in the way in which Duff takes that requirement to support a communicative theory. The distinction here is one between a reading of the

\footnotetext{
4 The force of the point is not lessened by the reflection that on my view, the nature of that message is one which we have no other means of expressing (Wringe 2006, pp. 179-180).

5 Especially since it is not clear that the proposed interpretation would even rule out a utilitarian justification of punishment.
} 
requirement not to treat others as a means in a way which is purely negative, and simply rules out certain kinds of behaviour, and a reading on which the requirement to treat others as ends-in-themselves has some kind of positive content. ${ }^{6}$ One attractive feature of Duff's communicative account is that by seeing the point of the harsh treatment which punishment involves as a way of engaging with the mind and character of the particular wrong-doer on whom it is inflicted, we can take it as being responsive to this stronger reading of the Kantian requirement.

This in turn suggests that Duff's account might be able to speak, in a way in which a denunciatory account cannot, to the idea that a plausible justification of punishment should be one which leaves open the possibility that the punished individual might come to accept that the punishing institution has some kind of legitimate authority over him or her. Of course, an advocate of the denunciatory account might say that a war criminal might come to accept the need for a policy of denunciatory communication expressed via sanctions imposed on people like him. But this is perhaps not quite the same thing: it seems that there is a subtle but still significant difference between an individual accepting that people who are like him should punished, and accepting that he in particular should be punished. ${ }^{7}$

Furthermore, I now think, someone who accepts my denunciatory account should be uncomfortable with ignoring the question of whether we can expect punished individuals to accept that their punishment is justified. On that account, the justification of both punishments and quasi-judicial processes involving war crimes is importantly non-standard. The fact that they are non-standard raises the question of whether individuals who have been submitted to such processes to have been subjected to them legitimately. An account which aims to leave it open that punished individuals might come to see the institutions through which they are being punished as having legitimate authority over them and to explain how they could be right in doing so seems to have an advantage here.

\section{Rethinking the Communicative Account: The Aspiration to Cosmopolitan Community}

None of this shows that a denunciatory account of war crimes punishments could not turn out to be the best we can come up with. However, it does suggest that if such an account could be either supplemented or replaced with a communicative account, the results might be more satisfactory. In the remainder of this paper, I shall not try to supplant the denunciatory account; but I shall try to suggest that it might be supplemented by a communicative account.

I suggested earlier that communicative accounts face the difficulty that individuals who are punished for war crimes might not see themselves as members

\footnotetext{
${ }^{6}$ Whether Kant intended his requirement to be read in this way is not a question which I shall take up here, but I think one can make a case that he did. I am influenced in this judgment by extensive discussion with my colleague Lucas Thorpe. For details, see Thorpe (forthcoming a, b).

7 It is perhaps worth adding that in situations where selective prosecution is likely to be common-as is arguably going to be the case for war crimes - this distinction seems significant. For more on the issue of selective prosecution see Wilkins (2001), Ellis (2001) and Wringe (2006).
} 
of the same community as the individuals who punish them. This matters, at least as far as Duff's account is concerned, since Duff takes the fact that individuals belong to the same community as those who punish them to play an important role in showing that punishments involving harsh treatment can legitimately be inflicted on them (Duff 2001).

The idea that war criminals can rightly be regarded as members of the same community as those who seek to inflict judicial punishments on them will strike many as implausible. In many cases we can expect war criminals to be tried and sentenced by citizens of states other than their own. However, we need to ask whether, in cases like this there could be some wider community of which both punisher and punished are members. It is certainly possible in general for two individuals who are members of distinct communities of one sort to share membership of a wider community. For example - to take a case of community which Duff treats as paradigmatic-members of different academic institutions might be citizens of one state. Analogously, citizens of distinct states might nonetheless be members of some further, wider community which extends beyond the borders of either state.

If this seems far-fetched, it is presumably because we normally take states to be the most extensive communities to which individuals belong. But though this might seem natural it is not obviously correct. Citizens of distinct European states which are both members of the European Union might, for example, see themselves as belonging to a European community which extends beyond national boundariesand to the extent that they are subject to a common set of regulations and shared institutions, and share a common political culture, they might well be correct to see things in this way.

This point does not ensure that in every case war criminals and those who seek to punish them will belong to one single community. To show this we would need some notion of a world community, to which all human beings belong. Despite its ancient provenance the idea of such a community may at first seem far-fetched. In order to establish the existence of such a community it is not enough to point out that all human beings have certain properties in common. (If there were a planet elsewhere in the galaxy which was identical in all respects to the earth but with whose citizens we could have no communication it would not follow that there was a community of which both we and they were members.)

Why then should we think that it makes any sense to think of there being a world community of which all human beings are members? Three considerations might point us in this direction. One line of thought goes back as far as Aristotle. In Book I of the Politics, Aristotle argues that it is a mark of political communities that they should be self-sufficient. It is far from clear how Aristotle himself understood this idea: on his view Greek city states were examples of political communities, and yet Aristotle was presumably well aware that such communities engaged in foreign trade (Aristotle 1941, 1252b-1253a).

Nevertheless, one might well hold that there was a sense in which individuals who are, as a matter of fact, economically dependent on one another should be seen as members of a single community. (We might still want to differ from Aristotle by recognising that units which were economically interdependent might have smaller parts which could also be seen as communities in their own right, so that simple 
economic interdependence was a sufficient condition for the existence of a community, but not constitutive of the only form of community worth considering in this context). If so, then there is a good empirical case for thinking that there is a very large community which comprises very many of the world's inhabitants even if not all of them.

This consideration is strengthened by a second point which is that insofar as different states enter into commercial relationships with one another or provide a home to economic entities which trade across national borders there are certain forms of regulation which apply transnationally. Thomas Pogge (Pogge 2001, Chaps. 4,6 ) has recently emphasised the negative side of this point: namely that to the extent that it makes sense to think in terms of their being a world economic order-by which he means the existence of a set of institutions and regulations, and not simply the existence of commercial relations between individuals or organizations in different parts of the world-we have obligations of justice to those who are affected by them. However, another implication of this line of argument is that the existence of an institutional structure of this sort establishes that the individuals who are subject to it can be seen as members of a common community.

A third consideration, which applies only to a subclass of war criminals, is nevertheless also worth mentioning. ${ }^{8}$ Leaders of states occupy a position which is defined by a wide range of formal rules and informal conventions. The existence of such conventions allows state leaders to act on behalf of the their populations in the diplomatic sphere, to conclude economic arrangements which may be to the detriment of parts of their population, to make laws which criminalise parts of their population and so forth. The fact that state leaders and their representatives have benefited from the existence of such rules seems to establish the existence of a community which goes wider than the nation state and of which they can reasonably be taken to be members. This would be true even if such conventions do not simply cease to exist in time of war, which in fact they do not.

\section{What Kind of Community Do We Need?}

At this point one might object that this is simply the wrong kind of community to appeal to for present purposes. The objection may, but need not come from someone unsympathetic to the project of extending a communicative account to the particular case of the punishment of war crimes. In this section I shall be dealing with an account developed in work by Anthony Duff $(2009,2010)$ which reaches a similar conclusion to mine but by what I take to be a somewhat different, and rather unsatisfactory route.

In answering the question "what sort of community do individuals need to belong to in order for punishment to be justified' we need to distinguish between two kinds of question. One is a conceptual question: what kind of community - if any-is

\footnotetext{
${ }^{8}$ Larry May (2007, Chaps. 12, 13) has recently argued that there are good reasons for thinking that in many cases, war crimes prosecutors should focus on the misdeeds of state leaders. What I say here points in the same direction.
} 
required for harsh treatment of one individual by another to constitute punishment? Another is a question of legitimacy: which kinds of community can legitimately punish their members?

Duff is interested in answering both kinds of question. He holds that it is a conceptual requirement on something's counting as punishment that punisher and punishee should be members of the same community, questions of justification are to be addressed at least in part by asking when it is legitimate for communities to convey messages via the harsh treatment that constitutes punishment (Duff 2010). I shall argue that although Duff's answer to the question 'what kinds of communities?' looks initially plausible as an answer to the question about legitimacy, it fails as an answer to the conceptual question.

Duff suggests that an advocate of communicative theories of punishment may hold that the sorts of communities which are required in order for talk of punishment to be in order need not be political communities and that it is enough if we can identify punisher and punishee as members of a single moral community. Clearly this suggestion needs to be filled out: Duff does so by alluding first to the Kantian notion of a 'Kingdom of Ends' and secondly-in language which suggests that he finds the notion more appealing — to Raimond Gaita's suggestion that human beings should be seen as members of a single community in virtue of their 'common humanity' (Gaita 2000, Chap. 3). ${ }^{9}$

This seems implausible. If it is right to think that for talk of punishment to be conceptually in order, punisher and punishee must be members of a single community, then there is something else which seems equally necessary. This is that in inflicting a punishment the individual enforcing the standards should be in a position to speak on behalf of the relevant community. This requirement seems to satisfied not just in cases of judicial punishments inflicted by states on their citizens but also in other cases where I think Duff would say that we rightly talk of punishment, such as punishments inflicted by religious bodies or academic institutions by their members, on children by their parents and so on: in each case we can see punishments as being determined by someone authorized to speak as the voice of the community.

Who, then might be authorized to speak on behalf of the moral community of mankind? The most obvious answers are 'anybody' and 'nobody'. Neither seems satisfactory: if nobody is authorized to speak then we seem to lose any grip on the idea that we can talk of punishment in this context; if anyone is authorized to speak then we seem to leave open the door to vigilante justice. Two other answers also seem problematic: that the righteous, or morally good are authorized to speak on behalf of the human community; and that the victims of wrongdoing are. The first would put many of those who, in practice institute war crimes trials into an unsustainably hubristic position; and the second seems to leave open the possibility of too many kinds of violation being effectively unpunishable.

\footnotetext{
9 I take Gaita's notion of 'common humanity' to be one that goes beyond ascribing human beings membership in a single community in virtue of a common property in the austere metaphysical sense of property: part of the idea, I think, is that humanity is something we possess not as separate individuals but as a collective. (The key idea would be, I think, that in some sense of the word human a single individual could not be a human being any more than they could be a state, or a football team: humanity in this sense involves treating oneself and others as having a certain status.).
} 
Perhaps most importantly of all, none of these answers seem able to explain, or to give us any indication how we might start to explain how any tribunal that could be constituted in the actual world, whether along the lines of an International Criminal Court, or along the more ad hoc lines of the Nuremberg Tribunals and the bodies which have dealt with war crimes in the former Yugoslavia could acquire the right to speak on behalf of a universal moral community. By contrast one might hope that if we could establish that war criminals and their judges were members of a single political community the questions about how international tribunals could speak on behalf of those communities might seem more tractable.

\section{The Problem of Non-State Punishment}

Suppose we accept that the idea of a world community makes sense. There are two reasons why we might still not immediately accept that the appropriateness of a communicative account of the punishment of war crimes. First, one might think that no community short of a state could have the authority to punish. Secondly, one might think that only communities in which membership is voluntary can justifiably punish and that it is central to the idea of a world community-at least as I have defended it - that one's membership of it is involuntary.

There are two kinds of reason for thinking that states are the only kinds of communities that can be justified in imposing punishments. One is fairly trivial; the second somewhat more substantive. The trivial reason is that one might take it to be definitive of some form of treatment's constituting punishment that it be inflicted by a state. Many people take it to be definitive of something's constituting punishment that it must be in response to transgression of a law. (Hart 1968) This, combined with the idea that only states can make laws, seems to entail that only states can punish. A fortiori, only states can inflict justified punishment.

We should not be over-impressed by this line of argument. The most straightforward response is obviously to say that nothing hangs on the use of the word 'punishment'. It is clear that communities can inflict harsh treatment on their members in response to violations of norms which are accepted in that community and we are interested in the question of whether certain forms of harsh treatment inflicted by certain communities are justified. However, this response is too concessive, for two reasons.

First, the claim that only states can make laws seems question-begging in this context. The issue of whether international law is genuinely a form of law is, admittedly a vexed one, with authoritative figures coming down on both sides (Kelsen 1947; Hart 1983; Raz 1970, 1979; Vinx 2007). ${ }^{10}$ In a debate over the punishment of war crimes it seems wrong to assume that the question has been settled in the negative.

\footnotetext{
${ }^{10}$ I thank Lars Vinx for useful discussion and pointers to relevant literature here.
} 
Secondly, it is not obvious that it is definitive of our notion of punishment that punishments can only be inflicted in response to transgressions of laws. We often talk of parents punishing their children, schools punishing their students, and professional associations punishing members who have violated professional standards; and there is no impropriety in this. If there is some insight embodied in the claim that punishment can only be in response to a violation of a law, it is that harsh treatment can only count as punishment when it occurs as a response to publicly promulgated norms. Nevertheless, communities other than states can promulgate norms publicly, and it seems hard to deny that international law is at least a set of publicly promulgated norms.

A more substantive reason for thinking that states are the only forms of community that can have a right to punish is that one might take states to be the only forms of community which can legitimately inflict the forms of harsh treatment which typically constitute punishment. (Duff seems unlikely to hold this view since he frequently refers to communities less extensive than states inflicting punishment. However, he could consistently do so, if he held that these communities held their right to punish in view of a delegation of punishing power by the state. Nevertheless, I suspect that this is not his view). In order to rebut this view we need to consider what might motivate it. One obvious possibility is that one might take the legitimacy of state punishment to derive from some sort of consent-actual or hypothetical - to one's membership of the state, along with its laws and legal system.

However, even if one accepts a consent based theory of political obligation-and it is not obvious, despite recent suggestions to the contrary that such accounts can be made to work (Gilbert 2006, pp. 215-238, p. 260) - that states' rights to punish individuals derive from the consent of punished individuals. An alternative view, which is Locke's is that the states' power to punish arises from individuals' delegation of their right to punish violations of the law of nature (Locke 1952, pp. 49-50). (This seems particularly noteworthy in view of Larry May's (May 2007, Chaps. 2-4) recent deployment of a natural law theory in his recent work on war crimes, despite the fact that the natural law theorist on whom he draws most explicitly is Grotius rather than Locke.)

\section{The Problem of Involuntary Membership}

That said, one might allow that communities other than states can have the right to punish, and still hold that it is only communities in which membership is voluntary which can legitimately punish their members (or at least which can legitimately punish their members on the basis of a communicative rationale). Duff appears to accept this view when talking about punishments administered by bodies such as religious bodies and academic institutions. However, if one thinks that this view is correct, then one might regard it as a problem for someone who wants to give a communicative account of the justification of punishments for war crimes, simply because membership in a world-wide community is not voluntary. 
In fact, though, I think that this point presents less of a problem for an advocate of the communicative view than one might at first think. In order to do this, we need to make two distinctions. The first is between arguments for the existence of a world-wide community which are based on human beings sharing some sort of common property (arguments which I rejected in Sect. 4) and arguments based on the existence of publicly promulgated norms. We should also distinguish between justifications of the punishment of war crimes which are aimed at showing that common soldiers can justifiably be punished, and justifications which are aimed at showing that state leaders and other individuals with command responsibility can be punished.

If the existence of a world-wide community was simply based on human beings sharing a common property it would follow that human beings' membership in this community was not voluntary. If the voluntariness of membership in a given community is indeed a requirement for the acceptability of a communicative theory of punishment which enforces the norms of that community then we cannot make a case for a communicative account of the punishment of war crimes along the lines which I have suggested.

However, I defended the idea of a world-wide community by reference not to a common property but to considerations of economic connectedness and the existence of publicly promulgated norms with a wider scope than the population of a particular state. I now want to distinguish between two separate strands of this argument, so as to come to different conclusions about the two kinds of cases of war crimes defendant that I distinguished earlier.

Consider first the case of state leaders. I argued earlier that one reason for taking there to be a world-wide community that embraced both those who had committed war crimes and those who sought to punish them derived form the existence of conventions defining the position and role of state leaders. We might call the community which exists in virtue of these conventions 'the community of nations.' It is plausible to claim that individual's membership in this community is voluntary. No-one has to be a state leader, after all. If this line of thought is correct, then we do not have to accept that the communicative justification of punishment fails because it is grounded in an individual's involuntary membership of a community.

Can this line of argument be extended to individuals below the level of state leaders with command responsibility? One might hope so, particularly in view of the difficulty — which Larry May has emphasized - in establishing the existence of mens rea in war crimes prosecutions of state leaders (May 2007, Chap. 12). But whether or not it can seems to depend on two issues, neither of which seem straightforward. The first is whether and to what extent the conventions which define the positions of state leaders also cover individuals who are appointed to positions by them. In the case of many civilian officials, it seems easy to make this case: the powers and privileges of such individuals often depend on them having been appointed by recognized heads of state; and to the extent that they do so they thereby depend on the existence of conventions that relate to the recognition of heads of state. It seems less clear that this is the case with military leaders.

The second issue that seems relevant to discussing whether individuals with command responsibility fall under the scope of a communicative justification of 
punishment by virtue of their membership of a community of nations is whether their membership in such a community can be seen as voluntary. It is not obvious that it can. The further down the chain of command responsibility one goes the less plausible claims of voluntary membership are likely to seem.

Once we reach the level of the common soldier, claims about both their membership in the community of nations, and claims that this membership can be seen as voluntary are apt to seem particularly problematic. So if we are interested in the possibility of a communicative justification of punishment we might want to look at other reasons for taking these individuals to be members of a world-wide community. (Such reasons, insofar as they apply to soldiers as such might also be expected to ground justifications of punishments for individuals with command responsibility below the level of state leaders other than their civilian appointees.)

There are two sorts of consideration that one might want to appeal to here. The first is based on considerations about the economic interdependence of individuals in separate nations. Call a community whose existence is based on such considerations 'the human community'. It seems implausible to hold that membership in a community of this sort is voluntary. There are two reasons for this. First, individuals may simply be unaware of their membership in the 'human community'. Secondly, most people, soldiers or not, do not have the option of withdrawing from economic activity in the way that would be required for their membership of the human community to be voluntary.

However, one might want to claim that there are considerations other than economic ones that establish that soldiers in particular are members of a community that goes beyond a single nation. In particular, one might hold that the existence of the sorts of norms which establish the existence of war crimes in the first casewhat are sometimes called the laws of war-establish the existence of a community of which they are a member-what one might call the 'community of combatants'.

Again, though, I think we should recognize problems with this way of justifying the applicability of a communicative justification of war crimes punishment to the case of common soldiers. The problems are of two kinds. First of all, if there are questions about the voluntariness of membership in what I have called the community of nations on the part of military officials, then there are also be questions about whether individual soldiers are always voluntarily members of the community of combatants. Soldiers who are drafted, or conscripted, or who find themselves involved in combat while undertaking compulsory periods of military service will often not be.

This line of thought presupposes that membership in the community of combatants might be voluntary simply because the conventions whose existence establishes the existence of the community of combatants were applicable to soldiers qua soldiers. The idea would then be that membership of the community of combatants would be voluntary to the extent that being a soldier was a voluntary matter. But even this may overstate matters since there is a strong case for seeing these conventions as being applicable to everyone, and not simply to soldiers (for example, they are typically taken to place restrictions on the permissibility of actions of the civilian commanders of these soldiers.) If so, then membership of the community of combatants is not voluntary. 


\section{Concluding Remarks}

I have argued that a communicative account of the punishment of war crimes might be viable despite my earlier concerns about whether war criminals can be regarded as members of the communities that punish them, as an account like Duff's seems to require. However, if we accept that an account of this sort can only justify punishment in cases where individuals are punished by communities in which their membership is voluntary we seem to need to distinguish between two different kinds of cases: that of common soldiers and that of political leaders.

One might draw one of two conclusions from this. Those who think that my arguments establish that a communicative account of the punishment of war crimes is vastly superior to a denunciatory account might conclude that - at least as far as international tribunals are concerned-our punitive practices should focus solely on individuals in leadership positions. (Nothing I have said rules out the justifiability of states trying and punishing common soldiers who perpetrate war crimes, though one might be doubtful as to how frequently this might occur.) However, this conclusion might seem unduly revisionary: it seems to give more credibility than one might like to a defence on the part of individual soldiers that they were 'only following orders'.

That said, a less revisionary conclusion might be in order. For one might still take the sorts of considerations raised by my earlier denunciatory account to have some weight in justifying the punishment of war criminals. On this view, the conclusion to draw would be that there are additional reasons for punishing individuals in leadership positions over and above those that apply to common soldiers. This might also justify a policy of focusing prosecutorial resources on such individuals, without our necessarily ceasing to regard the punishment of common soldiers as at least partly justifiable.

Acknowledgments I would like to thank Anthony Duff for making two forthcoming papers available to me as I was writing this, and for some useful email discussion of them; and Sandrine Berges, Amanda Burgess, and Saladin Meckled-Garcia for useful comments on an earlier draft (from which I have perhaps learnt less than I should).

\section{References}

Aristotle. 1941. Politics. In The basic works of Aristotle (ed. and trans: McKeon, Richard. New York: Random House.

Davis, Michael. 1991. Punishment as language: Misleading analogy for desert theorists. Law and Philosophy 10: 311-322.

Duff, Anthony. 2001. Punishment, communication and community. Oxford: Oxford University Press.

Duff, Anthony. 2009. Can we punish the perpetrators of atrocities? In The religious in responses to mass atrocities, ed. Thomas Brudholm, and Thomas Cushman. Cambridge: Cambridge University Press.

Duff, Anthony. 2010. Authority and responsibilty in international criminal law. In Philosophy of international law, ed. Samantha Besson, and John Tasioulas. Oxford: Oxford University Press.

Ellis, Anthony. 2001. What should we do with war criminals? In War crimes and collective responsibility: A reader, ed. Aleksandr Jokic. Malden MA: Blackwell.

Feinberg, Joel. 1970. The expressive function of punishment. In Doing and deserving, ed. Joel Feinberg. Princeton: Princeton University Press.

Gaita, Raimond. 2000. A common humanity: Thinking about love and truth and justice. London: Routledge. 
Gilbert, Margaret. 2006. A theory of political obligation. Oxford: Oxford University Press.

Hart, Herbert. 1968. A prolegomenon to the principles of punishment. In Punishment and responsibility, ed. Herbert Hart. New York: Oxford University Press.

Hart, Herbert. 1983. Kelsen's doctrine of the unity of law. In Essays in jurisprudence and philosophy, ed. Herbert Hart. Oxford: Clarendon Press.

Kelsen, Hans. 1947. Will the judgment in the Nuremberg trials constitute a precedent in international law? International Law Quarterly 1: 153-171.

Matravers, Matt (ed.). 1999. Punishment and political theory. Oxford: Hart Publishing.

May, Larry. 2007. War crimes and just war. Cambridge: Cambridge University Press.

Narayan, Uma. 1993. Appropriate responses and preventive benefits: Justifying censure and hard treatment in legal punishment. Oxford Journal of Legal Studies 13: 166-182.

Pogge, Thomas. 2001. World poverty and human rights. Cambridge: Polity Press.

Raz, Joseph. 1970. The concept of a legal system. Oxford: Clarendon Press.

Raz, Joseph. 1979. Kelsen's theory of the basic norm. In The authority of law: essays on law and morality, ed. Joseph Raz. Oxford: Oxford University Press.

Thorpe, Lucas. (forthcoming a). Is Kant's realm of ends a Unum per Se? British Journal of the History of Philosophy.

Thorpe, Lucas. (forthcoming b). Kant on the relationship between autonomy and community. In Kant and community, eds. Lucas Thorpe and Charlton Payne. Rochester: Rochester University Press.

Wilkins, Burleigh. 2001. Whose trials? Whose reconciliation. In War crimes and collective responsibility: a reader, ed. Aleksandr Jokic. Malden, MA: Blackwell.

Vinx, Lars. 2007. Hans Kelsen's pure theory of law: Legality and legitimacy. Oxford: Oxford University Press.

Wringe, William. 2006. Why punish war crimes? Victor's Justice and Expressive Justifications of Punishment' Law and Philosophy 25: 159-191. 